Journal of Engineering and Applied Sciences 15 (4): 888-897, 2020

ISSN: 1816-949X

(C) Medwell Journals, 2020

\title{
Activating Organizational Culture to Achieve Requirements of Management by Wandering Around
}

\author{
Mahmoud Shuker Mohammed and Abdulazeez Barrak Mohsin \\ Department of Business Management, \\ Al Mamoun University College, 10011 Baghdad, Iraq
}

\begin{abstract}
The study aimed at identifying the role of management by wandering around in developing the service companie's performance by studying theoretical and experimental aspects of the issue and linking them with the field statistical analysis results includes some reasons, the extent the efficiency and the effectiveness of the management by wandering around is available in the field of electrical industries. Also, the obstacles facing the management by wandering around in the field of electrical industries. Moreover, the type of the relationship between components of management by wandering around and the basic axes of the changing process. Accordingly, the study aimed to examine the following hypotheses like a statistically significant relation between management by wandering around and the modern transformational method's application in the field of the electrical industries in Iraq as well as efficiency and the effectiveness of the organizational culture in the field of the electrical industries.
\end{abstract}

Key words: Management by wandering around, organizational culture, electrical, industries, organizational, statistical

\section{INTRODUCTION}

The state company for electrical and electronic industries is facing several challenges that limit the revitalization of the organizational culture to achieve the requirements of management by wandering around. The following questions identify the problems facing the state company of electrical and electronic industries like a significant correlation between the organizational culture and achieving the requirements of management by wandering around. Secondly, organizational culture helping to improve the skills of management by wandering around. Thirdly, the problems and challenges facing the stat company for electrical and electronic industries in achieving the requirements of management by wandering around. Finally, the company cares about increasing the efficiency of the employee's performance as a way to change its organizational culture (Hammid, 2013).

The aim of this study is to improve the organizational culture and effective policies to achieve pioneering leadership in a renewable competitive environment. The study's significance can be represented by the following like firstly, the importance of improving the organizational culture in the electrical and electronic industry sector. Secondly, creating new leadership able to change the company's strategies. Hence, increase production and develop the national and local economy. Thirdly, enriching the Iraqi encyclopedia (library) in specific and the Arabian encyclopedia in general by these studies. The study adopted the analytic descriptive approach and the statistical one. The study came up with the following results, the application of the programs of management by wandering around in a specific and scientific way affects positively on the achievement of the company's goals. Also, the desire of the employees in the field of the electrical industries to take part effectively in the process of applying the modern methods in management by wandering around was noticeable. Outermore, there is a clear organizational culture in the sector (Hammid et al., 2016).

Previous studies: A comprehensive revision has been made on related literature, also on the related foreign and Arabic studies.

Independent variable (management by wandering around): The purpose of the study was to examine the impact of implying management by wandering on healthcare employees in one of the German hospitals (Beil-Hildebrand, 2006). Management by wandering was considered as one of the procedures that increase the employees' commitment. In addition, it supports high trust and shared understanding. This study took six months to examine the daily labor life in the hospital's nursing section. In this study, management by wandering was used as a means of organizational control, as a result; the internal promotion of soaring values and path-finding was met with both skepticism and cynicism. Pre commitment and motivation levels were high among healthcare employees, they were passionate about their 
work and they actively engaged in open communication and organizational development. But all this had little to do with what management by wandering is about and its implications raise questions about its influence on high trust work relations more generally (Hammid, 2016).

Thomas and French (1985) the study aimed to identify the level of practicing management by wandering around and its impact on the efficiency of kindergarten teachers. An application was made to collect the study data, the study community consisted of 103 kindergarten teachers, results has shown the following.

The purpose of using management by wandering around was to increase the efficiency of kindergarten teachers as it showed $56.9 \%$ of the discrepancy. The study has been summarized in several recommendations. Mainly, the fact that the ministry of education should enhance practicing management by wandering and the efficiency of kindergarten teachers by increasing conscious and participation in decision-making. Moreover, hold training and awareness-raising courses. Thus, this will increase loyalty and performance in addition to improving the educational process (Hammid et al., 2018a-c).

The purpose of the study was to recognize the fact of using management by wandering by principals in governmental high schools in the city of Riyadh according to the following variables (experience in management, education, type of school building) as well as the requirements for implementing management by wandering. The study was applied by 186 of high school principals, approximately $95.9 \%$ of the community. In addition, using the descriptive survey method as data was encoded using statistical analysis, results have shown the following.

The degree of practicing management by wandering byschool's principals was extremely low. The barricades of practicing management by wandering by school principals in Riyadh were quite low. There were no statistical differences between the respondent's answers attributed to the years of experience, scientific qualification and type of school variables (Hammid et al., 2018a-c).

\section{Dependent variable}

Organizational culture: A study by Hammid and Sulaiman (2017) the purpose of the study is to determine the concept of organizational organization and analyze its impact on the performance of the employees in Dan Fodio Holding Corporation. A questionnaire of 16 paragraphs has been designed to identify the organizational issue that affects the performance of the employees. The study consisted of 147 purposive samples. The study recommends spreading the organizational culture among individuals. Also, it emphasizes evaluation, monitoring and developing methods. Furthermore, create a suitable organizational environment to apply new ideas and methods at work. A study by Hammid et al. (2019), entitled by the effect of organizational culture and by roaming style on job satisfaction and organizational commitment. The purpose of the study is to recognize the impact of organizational culture and by roaming style on job satisfaction and organizational commitment for a sample of principals in Hong Kong and Australia, the sample size reached 317, 201 from Hong Kung and 116 from Australia who works in telecommunication and banking fields. Results have shown statistical differences between the two countries, achievement and humanity were common in the Australian organizations. While organizations in Hong Kong were dominated by the organizational culture and management. In addition, the organizational culture and roaming style has some advantages for job satisfaction and organizational commitment (Hammid et al., 2018a-c).

\section{MATERIALS AND METHODS}

Research design: The following chart illustrates the nature of the relationship between the study's variables as illustrated in Fig. 1 and 2. The hypothesis of the study are: there is a significant relationship between the organizational culture and the application of management by wandering around. There is an impact of organizational culture on the application of management by wandering around.

\section{Population and sample of the study}

The company: The state company of electrical and electronic industry is considered as one of the companies of the Ministry of Industry and Minerals that was established in 1974, the company has 8 factories in the same site, it's sponsored by an owner authorized to support the continuance of its business.

A sample of the study: A purposeful sample consisted of the company's managers and their assistants were selected. The 57 questionnaires were directly disseminated, 45 of them were retrieved. Hence, the retrieval percentage has reached $80 \%$ noting that the study's population consisted of 65 respondents.

Instrument of the study: Data were collected using a questionnaire which addressed two types of questions, the first one is about the personal information of the sample, the second one is about the research variables that depended on a group of standard parameters in similar studies and researches. In addition, formulating questions that serve the subject of the research which has been apparently approved as illustrated in Table 1. The questionnaire was designed according to the instruments of similar studies, for instance (Hammid et al., 2018a-c; Sakarneh and Ibrahim, 2011). 


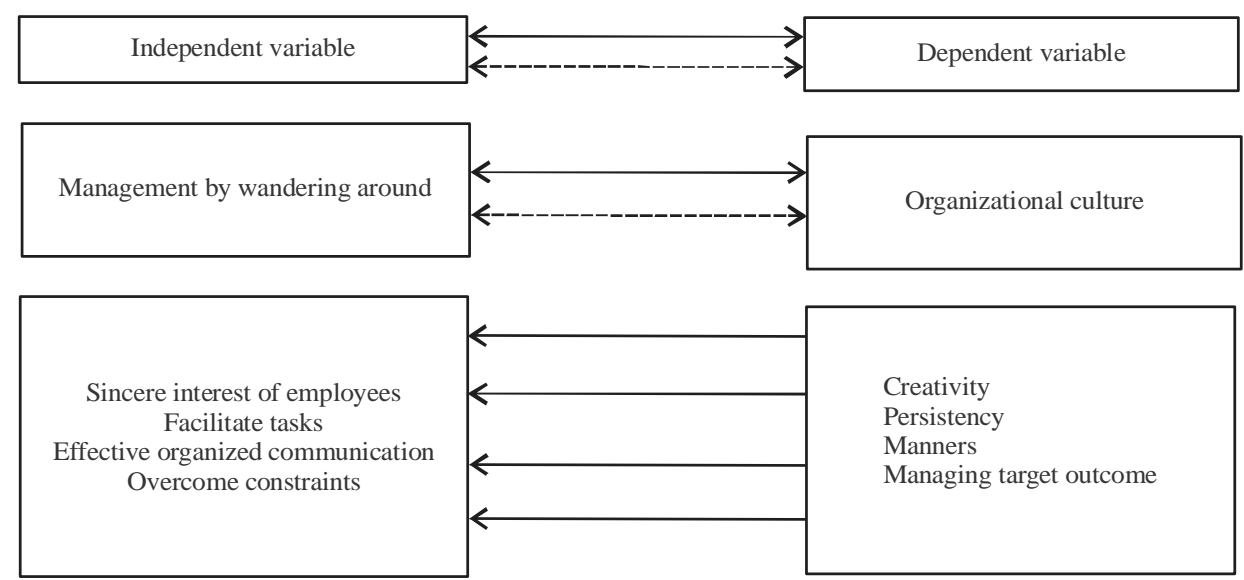

Fig. 1: The nature of the relationship

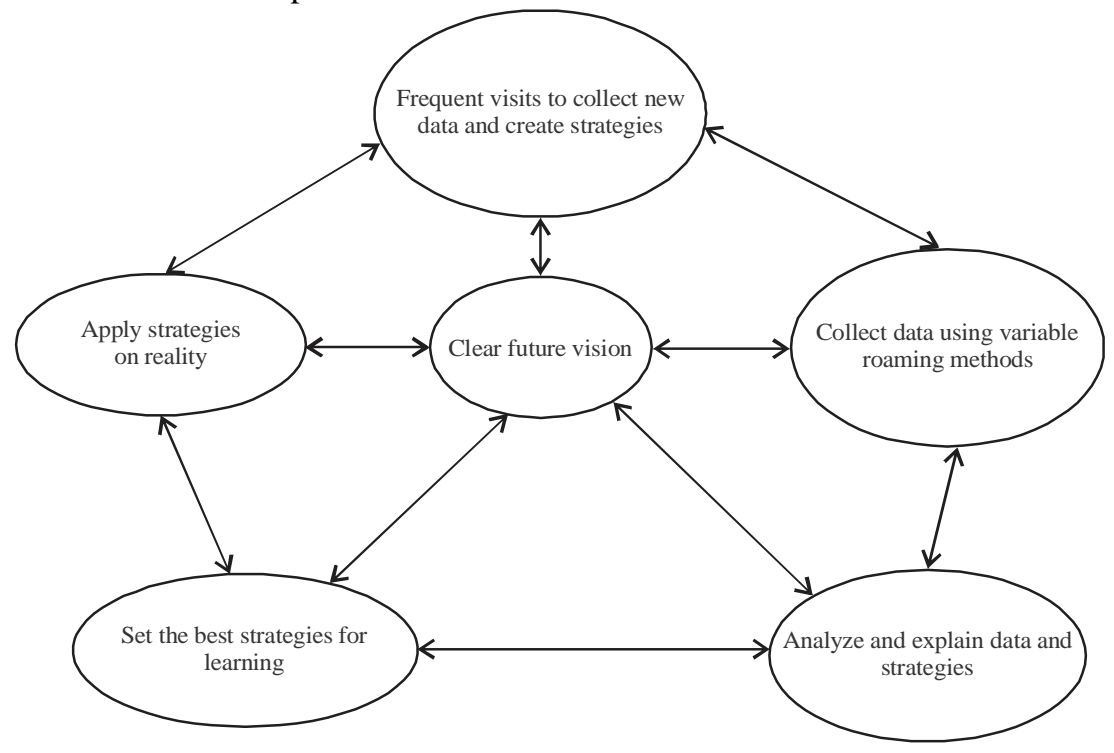

Fig. 2: The stages of developing the organizational process

\begin{tabular}{llrr}
\multicolumn{2}{l}{ Table 1: Formulating questions that serve the subject of the research } & \\
\hline Variables & Description & Individuals No. & Percentage \\
\hline Scientific qualification & Master & 33 & 75 \\
& Bachelor & 12 & 25 \\
Position & Total & 45 & 100 \\
& Manager & 10 & 22 \\
& Assistant manager & 13 & 29 \\
Years of experience & Departmental manager & 22 & 49 \\
& Total & 45 & 100 \\
& $<10$ & 14 & 32 \\
& Less & 10 & 20 \\
& Less & 15 & 35 \\
& $30+$ & 6 & 13 \\
\hline
\end{tabular}

Statistical methods: The mean: to identify the study's variables' level.

Standard deviation: To measure the spread out of numbers from the arithmetic mean.
Spearman's rank correlation: To measure the strength and direction of the association between study variables.

Simple linear regression factor: To test the impact of the independent variable on the independent variable. 
Table 2: Comparing the old culture with new work

\begin{tabular}{ll}
\hline New work & Old culture \\
\hline Individuals follow their instincts & Individuals follow instructions \\
Individuals follow the manger that elected & Individuals are led by the manager \\
Groups depend on teamwork & Groups follow the manager \\
Teamwork can affect the organization & Individual work can't affect the organization \\
\hline
\end{tabular}

The second research: frame analysis: This research will discuss two major variables: organizational culture and management by wandering which contributes to answering the research hypotheses, issues in addition to achieving the ultimate goals. These variables will be illustrated as the following.

\section{Organizational culture}

Concept: The tenets and values of the organization members which aim to achieve the ultimate objective, it could be written, perceived and collaboratively created by individuals. Moreover, it could be taught to new employees (Hammid et al., 2018a-e; Sakarneh and Ibrahim, 2011). Based on that, the organizational culture can also be defined as a group of common beliefs that control the interactions between employees and other parties outside the organization. This could be an advantage (competitive advantage) or a disadvantage according to its impact on the employee's attitudes. Hence, successful organizations are based on hardworking, values and persistence. The organization does not welcome individuals who reject enhancing and developing their capabilities (Be'eri-Shlevin et al., 2012; Hammid and Sulaiman, 2018a-e).

Role of organizational culture: Some organizations try to highlight the importance of organizational culture and its impact on employees as it has an important role in cultivating good manners and attitudes. Furthermore, it helps employees to perform their roles appropriately, especially, the informal, spontaneous attitudes (Hammid et al., 2018; Toth et al., 2000).

Types of organizational cultures: Cultures vary according to the influence of values, beliefs and thoughts on individuals, the culture of military organizations radically varies from the technical organization. Hereinafter an illustration for that (Hammid et al., 2018; Mirtaheri, 2016):

Power culture: It's the dominating power of one individual (or a number of individuals) who impose their respect on everyone, this culture could be found in small organizations, especially, the family-based ones as those organizations operate without any working norms or regulations (Ripke et al., 2013).

Role culture: It's an organizational culture that is based on bureaucracy where experience and specialization are the sources of power and legitimacy as well as society (Al-Ma’ani et al., 2014; Hammid et al., 2017a-b).

Task culture: This culture is based on performing projects and tasks. Mainly, this culture concerns skills and creative individuals (Hammid et al., 2017; Jaradat et al., 2013a-b).

Dimensions and components: O’Reilly, Stagat and Caldwell have defined five dimensions of cultural organization.

Creativity: It expresses the development and acceptance of applying new thoughts, processes, products or new services.

Constancy: It depends on using one paradigm of values, standards, practices, norms and assumptions as this accord with creativity and development within a fixed period of time (Dirat et al., 2011).

Respect: One of the major components of culture is the mutual respect among organization members.

Goal-orientation leadership: Focus on achieving a particular quality of outcome by employees.

Instructions: Steps that lead employees in performing their tasks. The difference between old and new organizational culture according to teams, teamwork, intimacy, organization, sense of cultural belonging at work and equality among employees, hereby the differences between old and new culture as illustrated in Table 2.

\section{Management by wandering}

Concept: The concept came from the inflation of companies, the spread of projects, diversity of its business and the geographical distance. As management by wandering is an integrated system with coordinated components and dimensions. Furthermore, it works on breaking barricades and processing/managing the cases of alienation (Connolly et al., 2000). Al-Salmi clarifies his viewpoint on the roaming manager, he believes that it is a leap of knowledge that eliminates the limits of interaction between the organizational levels for a better production process (Gilbert et al., 2005). He also defines it as the type of management that focuses on human 


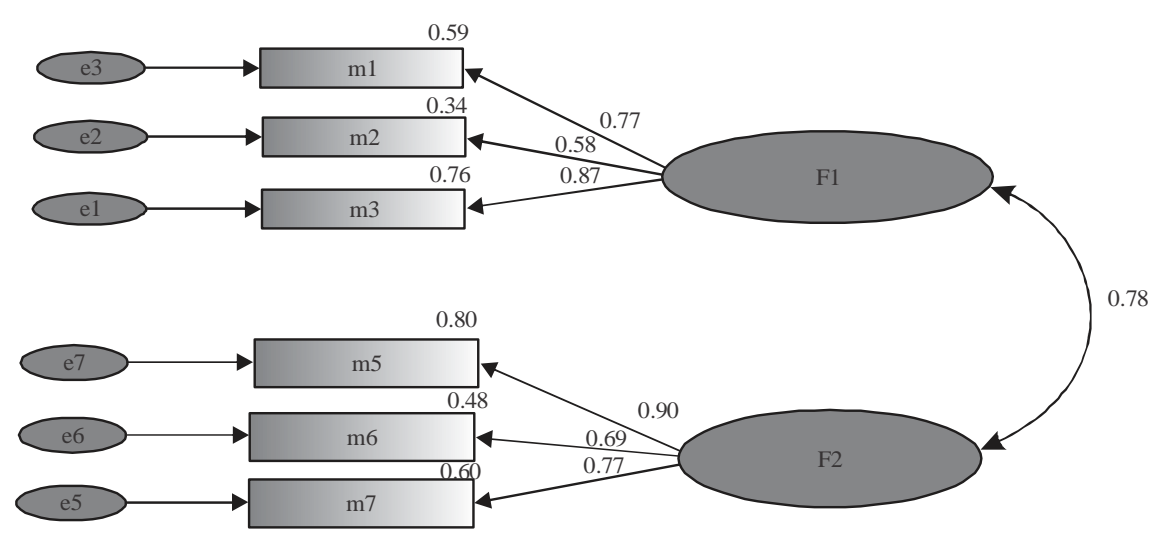

Fig. 3: Management by Wandering around

relationships, open evaluation and awareness are crucial to building a strong work ethic and great performance. In addition, he believes that the dominant strategy is not effective in modern organizations (Hammid et al., 2013).

The role of management by wandering: Many types of research including the ones by parker, indicate the importance of management by wandering and supervisory as the manager should check all premises, work closely with employees and realize facts at the workplace (Hu and Bentler, 1999).

Stages of management by wandering: To apply management by wandering there must be a thoroughly comprehensive study of the current situation of the company. The study includes the nature of management, daily decision-making process and instructions. Hereby the five main stages of applying management by wandering (Gonnella, 2011):

- $\quad$ Visit the workplace frequently if any problem occurs

- Use the suitable thinking method to find alternative solutions to the problem (Benabderrahmane et al., 2010)

- Take preventive and immediate actions to prevent, follow and solve the problem (Bhagwat, 2015)

- Discuss and follow the problem directly with employees after each visit for group-decision making.

- A manager should be patient to gain the trust of employees (Venters and Whitley, 2012)

The previous model can be demonstrated as the following:

- The clearreality-based vision for the future

- Collect and explain data for the current situation and create new strategies for development

- Apply these strategies to reality for better results
Principles of management by wandering: The effective application of management by wandering requires several qualified leaders for employees; the most prominent principles are the following:

- $\quad$ Sincere care for employees

- Facilitate tasks

- Effective organized communication

- High level of cooperation

The practical framework

Firstly: The instrument's validity: the validity of the model includes the following.

\section{Firstly}

Validity: Indicates assuming data with a common factor if the correlation percentage was high: it can be measured as the following.

Loading data: Down below the form shows the correlation between teamwork and the cultural organization. After isolating the impact of persistency, manners and new culture, the correlation percentage reached 0.77 . It is noteworthy that this indicator should be in the range of $0.20-0.90$. As the following form shows, all these correlations fall within this range as shown in Fig. 3.

Chi-square 13.455; freedom degree 13; significance level 0.413; standard Chi-square 1.035; comparative fit index 0.994; Tucker-Lewis index 0.990; Ramsey index 0.039; F1 represents cultural organization; F2 represents management by wandering around.

Indicators of value conformity with data: The previous form shows that the fit indexes were all within the acceptable range. For instance, the comparative fit index reached 0.994 which is higher than 0.90 , this implies that the sample must fit with data. 
J. Eng. Applied Sci., 15 (4): 888-897, 2020

Table 3: Matrices (group No. 1-default model) factor score weights (group No. 1-default model)

\begin{tabular}{lcccccc}
\hline & $\mathrm{m} 5$ & $\mathrm{~m} 6$ & $\mathrm{~m} 4$ & $\mathrm{~m} 1$ & $\mathrm{~m} 2$ & $\mathrm{~m}$ \\
\hline F2 & 0.451 & 0.111 & 0.053 & 0.035 & 0.017 & 0.063 \\
F1 & 0.105 & 0.026 & 0.283 & 0.188 & 0.090 & 0.333 \\
\hline
\end{tabular}

Default model test: According to the following matrix, the model is free of double error, for instance, teamwork development data belongs more to the concept of cultural organization than to management by wandering as illustrated in Table 3.

\section{RESULTS AND DISCUSSION}

Reliability: Reliability is one of the characteristics of a good measurement tool, it's the constancy of the value, as the test achieves the same results if it's under the same group and circumstances. Its better if the reliability factor is close to 1 , the reliability value reached 0.930 ; this indicates that it's reliable as illustrated in Table 4.

Validity: It measures the findings that need to be measured, it is equal to the square root of the reliability factor (0,969). This implies that the validity factor measures the findings of cultural organization and management by wandering.

Secondly: answers analysis: The dependent variable (Management by wandering): the following table shows the average, standard deviation, variation factor of data, agreement of samples and frequency distribution of the dependent variables as illustrated in Table 5.

According to the table, the average is 4.07 which is bigger than the mean median that has reached 3 , the standard deviation is 0.07 , the deviation factor is 0.64 and the agreement of samples from 1-22 is 81.4.

The data have achieved high averages, this indicates that management by wandering has created a clear vision for the future of Diyala Company for Electric Industries; as this type of management adjusts with work and different levels of relationships at the company, guides the goals and values of conformity at the company, presents solutions for different situations, creates an effective environment at the workplace and it seeks suggestions from the employees for decision making. The values, policy, hierarchy and the nature of work all influence management by wandering which in turn depends on connecting with managers, setting objectives and procedures that reflect the company's vision, dedicating a share of resources to support individual work. Management by wandering can be used as a way of convincing employees that they can achieve what they strive for. In addition, build suitable data for the company, use effective learning to build the necessary skills, compensate qualified employees and provide material and moral incentives. Furthermore, management by wandering affects employees using style, intelligence, confidence, experience (technical, manufacturer and behavioral one) and leadership by persuasion technique. As for the entries 17.20, 22, they have achieved an average lower than the mean median, this indicates that management by wandering around does not depend on reward punishments to influence the performance of the employees, it also does not use the perspective leadership. The following table shows the average, standard deviation, variation factor, agreement of samples and frequency distribution for the data of a cultural organization.

The table shows that the variables of the cultural organization have achieved the average of 3.92, a standard deviation of 0.62 , a deviation factor of 0.158 and a degree of agreement 78.4. The entries of management by wandering have reached high averages in diyala company. The company believes in the importance of cultural organization as it creates a suitable environment for new employees, it signifies creative individuals, it encourages new inventions and suggestions, it frequently identifies the cultural organization of similar companies and it restores replaces the company's business when necessary. In addition, the company adopts the change and adaptation processes for any external influences, it leads employees in the identification processes, it perceives tasks depending on repeated instructions, it imitates the strategies of others in solving problems, it evolves many ideas easily in a short period of time, it accepts opposing views and it discovers the weaknesses and strengths of work. Moreover, it requires detailed instructions for new tasks. In item 28, the company has achieved an average lower than the mean median, this indicates that management by wandering does not receive a law quality of human and material resources.

Assumptions test: The following table shows the weak impact of team development on management by wandering around, increasing development in 100\% leads to using management by wandering around in $27 \%$, the insignificant estimator formulated the p-value for t-test which is 0.012 , it's $<5 \%$ as illustrated in Table 6.

The following table shows that the insignificant estimator formulated the $p$-value for $f$ test which is (0.012), its \%5 less than the estimating level as illustrated in Table 7. 
J. Eng. Applied Sci., 15 (4): 888-897, 2020

Table 5: Answers analysis to variables of management by wandering

\begin{tabular}{|c|c|c|c|c|c|c|c|c|c|c|}
\hline $\begin{array}{l}\text { Variables of } \\
\text { management }\end{array}$ & $\begin{array}{l}\text { Totally } \\
\text { don’t agree }\end{array}$ & $\begin{array}{l}\text { I don't } \\
\text { agree }\end{array}$ & $\begin{array}{l}\text { Certain } \\
\text { extent }\end{array}$ & Agree & $\begin{array}{l}\text { Totally } \\
\text { agree }\end{array}$ & Average & SD & $\begin{array}{l}\text { Variation } \\
\text { factor }\end{array}$ & $\begin{array}{l}\text { Agreement } \\
\text { of samples }\end{array}$ & $\begin{array}{l}\text { Sample's } \\
\text { No. }\end{array}$ \\
\hline Develop employee’s performance & - & - & 3 & 34 & 6.00 & $\mathrm{C}$ & 0.47 & 0.114 & Very good & 43 \\
\hline Act like a role model for employees & 1 & 4 & 1 & 24 & 14.00 & 4.07 & 0.96 & 0.237 & Very good & 44 \\
\hline Encourage teamwork & - & - & 3 & 34 & 7.00 & 4.09 & 0.47 & 0.114 & Excellent & 44 \\
\hline Encourage employees & 2 & - & - & 35 & 7.00 & 4.02 & 0.76 & 0.189 & Very good & 44 \\
\hline Encourage employees to achieve more & - & 1 & 3 & 22 & 18.00 & 4.30 & 0.70 & 0.162 & Very good & 44 \\
\hline Encourage employees to figure out solutions & - & - & 4 & 18 & 22.00 & 4.41 & 0.65 & 0.147 & Very good & 44 \\
\hline Suggest new strategies for task achievement & 1 & 4 & & 24 & 14.00 & 4.05 & 0.96 & 0.237 & Very good & 44 \\
\hline $\begin{array}{l}\text { Give employees chances to think } \\
\text { about new strategies }\end{array}$ & - & - & 4 & 18 & 22.00 & 4.41 & 0.65 & 0.147 & Very good & 44 \\
\hline Respect viewpoints of employees & - & 1 & 5 & 31 & 7.00 & 4.00 & 0.61 & 0.152 & Excellent & 44 \\
\hline Treat employees & 1 & - & 7 & 20 & 16.00 & 4.14 & 0.85 & 0.205 & Excellent & 44 \\
\hline Consider the ignored employees & 1 & - & - & 23 & 20.00 & 4. 39 & 0.72 & 0.164 & Excellent & 44 \\
\hline Encourage taking responsibility & - & - & 3 & 28 & 13.00 & 4.23 & 0.56 & 0.132 & Excellent & 44 \\
\hline Support individual work & - & 1 & 7 & 24 & 12.00 & 4.06 & 0.80 & 0.197 & Very good & 44 \\
\hline Authorize employee’s organizational tasks & - & - & 3 & 30 & 11.00 & 4.18 & 0.54 & 0.129 & Very good & 44 \\
\hline Appreciate employees & 1 & - & 3 & 39 & 11.00 & 4.11 & 0.72 & 0.175 & Very good & 44 \\
\hline Suggest new strategies & 1 & 4 & 2 & 26 & 11.00 & 3.95 & 0.93 & 0.235 & Excellent & 44 \\
\hline Create a collaborative environment & 38 & 5 & - & 1 & - & 1.18 & 0.54 & 0.457 & Good & 44 \\
\hline Discuss goals frequently & - & - & 5 & 27 & 12.00 & 4.16 & 0.61 & 0.146 & Very good & 44 \\
\hline Focus on the vision of the organization & - & - & - & 26 & 18.00 & 4.41 & 0.53 & 0.120 & Very good & 44 \\
\hline Involve employees in decision making & 9 & 16 & 7 & 8 & 4.00 & 2.59 & 1.26 & 0.486 & Acceptable & 44 \\
\hline $\begin{array}{l}\text { Equate authority with responsibility } \\
\text { when giving authorization }\end{array}$ & - & - & 4 & 23 & 17.00 & 4.30 & 0.63 & 0.146 & Very good & 44 \\
\hline Provide employees with data after meeting & 9 & 16 & 7 & 8 & 4.00 & 2.59 & 1.26 & 0.286 & Acceptable & 44 \\
\hline The company have used new strategies & 1 & - & - & 23 & 20.00 & 4.39 & 0.72 & 0.164 & Very good & 44 \\
\hline granted patent rights for new inventions & 3 & 3 & 7 & 13 & 18.00 & 3.91 & 1.21 & 0.309 & Good & 44 \\
\hline Discover problems and find solutions & - & - & 3 & 31 & 10.00 & 4.16 & 0.60 & 0.144 & Very good & 44 \\
\hline Take risks & - & - & 5 & 28 & 11.00 & 4.14 & 0.59 & 0.142 & Very good & 44 \\
\hline Don’t hesitate to make a change & - & - & - & 26 & 18.00 & 4.41 & 3.53 & 0.120 & Acceptable & 44 \\
\hline new instructions to use materials & 13 & 25 & 2 & 2 & 2.00 & 1.98 & 0.97 & 0.489 & Very good & 44 \\
\hline Encourage suggestions & 1 & - & 3 & 29 & 11.00 & 4.11 & 0.72 & 0.175 & Excellent & 44 \\
\hline $\begin{array}{l}\text { The company has updated the } \\
\text { software and data system }\end{array}$ & - & - & 7 & 28 & 8.00 & 3.98 & 0.66 & 0.165 & Excellent & 44 \\
\hline The company has made root changes & - & - & 6 & 34 & 4.00 & 3.95 & 0.48 & 0.121 & Very good & 44 \\
\hline $\begin{array}{l}\text { The company has made changes } \\
\text { in its organizational structure }\end{array}$ & - & 1 & 2 & 31 & 10.00 & 4.14 & 0.59 & 0.142 & Good & 44 \\
\hline $\begin{array}{l}\text { The management has provided knowledge } \\
\text { for the company }\end{array}$ & 1 & 1 & 18 & 20 & 4.00 & 3.57 & 0.79 & 0.221 & good & 44 \\
\hline $\begin{array}{l}\text { The company saves suggestions, } \\
\text { experiences and tests in a database }\end{array}$ & - & - & 3 & 34 & 7.00 & 3.77 & 0.80 & 0.212 & Excellent & 44 \\
\hline $\begin{array}{l}\text { The creates a suitable environment } \\
\text { for the employees }\end{array}$ & - & - & 7 & 33 & 4.00 & 3,93 & 0.50 & 0.127 & Good & 44 \\
\hline The company has a flexible system & - & - & 14 & 27 & 3.00 & 3.75 & 0.58 & 0.154 & Very good & 44 \\
\hline The company tries to gain knowledge & - & - & 47 & 18 & 22.00 & 4.41 & 0.65 & 0.147 & Good & 44 \\
\hline $\begin{array}{l}\text { the ability to make quick decisions } \\
\text { for contingencies }\end{array}$ & - & - & 7 & 30 & 5.00 & 3,86 & 0.47 & 0.173 & Very good & 44 \\
\hline Authorize some qualified employees & 1 & 1 & 5 & 19 & 19.00 & 4.25 & 0.83 & 0.195 & Good & 44 \\
\hline Total & & & & & & 3.92 & 0.62 & 0.158 & & 44 \\
\hline
\end{tabular}

Table 6: Coefficient

\begin{tabular}{|c|c|c|c|c|c|}
\hline \multirow[b]{2}{*}{ Variables } & \multicolumn{2}{|c|}{ Unstandardized coefficients } & \multicolumn{3}{|c|}{ Standardized coefficients } \\
\hline & t-values & Sig. & B & SE & Beta \\
\hline Constant & 1.477 & 0.356 & & 4.155 & 0.000 \\
\hline Staff development & 0.270 & 0.103 & 0.367 & 2.616 & 0.012 \\
\hline
\end{tabular}

Table 7: ANOVA test

\begin{tabular}{lllccr}
\hline Model & Sum of squares & df & Mean square & F-values & Sig. \\
\hline 1 & Regression & 3.762 & 1 & 3.762 & 6.841 \\
& Residual & 24.199 & 44 & 0.550 & 0.012 \\
& Total & 27.961 & 45 & \\
\end{tabular}


J. Eng. Applied Sci., 15 (4): 888-897, 2020

$\underline{\text { Table 8: Coefficient }}$

\begin{tabular}{|c|c|c|c|c|c|}
\hline \multirow[b]{2}{*}{ Model } & & Unstandardized coefficients & \multicolumn{3}{|c|}{ Standardized coefficients } \\
\hline & t-values & Sig. & $\mathrm{B}$ & SE & Beta1 (constant) \\
\hline & 1.574 & 0.256 & & 6.156 & 0.000 \\
\hline Constancy and courtesy & 0.270 & 0.076 & 0.472 & 3.553 & 0.001 \\
\hline \multicolumn{6}{|l|}{ Table 9: ANOVA test } \\
\hline Model & Sum of squares & $\mathrm{df}$ & Mean square & F-values & Sig. \\
\hline \multirow[t]{3}{*}{1} & Regression & 5.025 & 1 & 5.025 & 12.622 \\
\hline & Residual & 17.516 & 44 & 0.398 & 0.001 \\
\hline & Total & 22.541 & 45 & & \\
\hline
\end{tabular}

Table 10: Coefficient

\begin{tabular}{|c|c|c|c|c|c|}
\hline \multirow[b]{2}{*}{ Models } & \multicolumn{2}{|c|}{ Unstandardized coefficients } & \multicolumn{3}{|c|}{ Standardized coefficients } \\
\hline & t-values & Sig. & $\mathrm{B}$ & $\mathrm{SE}$ & Beta \\
\hline Constant & 1.833 & 0.293 & & 6.261 & 0.000 \\
\hline New culture & 0.216 & 0.101 & 0.307 & 2.136 & 0.038 \\
\hline \multicolumn{6}{|c|}{ Table 11: ANOVA test } \\
\hline Models & Sum of squares & $\mathrm{df}$ & Mean square & F-value & Sig. \\
\hline Regression & 2.118 & 1 & 2.118 & 4.562 & 0.038 \\
\hline Residual & 20.423 & 44 & 0.464 & & \\
\hline Total & 22.541 & 45 & & & \\
\hline
\end{tabular}

Table 12: Cultural organization

\begin{tabular}{lcccc}
\hline Management by wandering around & Staff development & Constancy and courtesy & New culture & Total of cultural organization \\
\hline Good treatment & $0.509^{*}$ & $0.418^{*}$ & $0.507^{* *}$ & $0.498^{* *}$ \\
Facilitating organizational tasks & 0.304 & $0.503^{* *}$ & 0.378 & $0.521^{* *}$ \\
Effective communication & $0.523^{* *}$ & $0.528^{* *}$ & $0.552^{* *}$ & $0.72^{* *}$ \\
Total of management by wandering & $0.55^{* *}$ & $0.60^{* *}$ & $0.54^{* *}$ & $0.68^{* *}$ \\
\hline
\end{tabular}

The impact of constancy and courtesy on using management by wandering test. The following table shows the weak impact of staff development on management by wandering, increasing development in $100 \%$ leads for using management by wandering in $27 \%$. The insignificant estimator formulated $t$ value for the test which is 0.001 , it's $5 \%$ less as illustrated in Table 8 . The following table shows that the insignificant estimator formulated p-value for $\mathrm{f}$ test which is 0.012 , it's $5 \%$ less as illustrated in Table 9. The impact of developing a new culture in management by wandering around test: the following table shows the weak impact staff development on management by wandering, as increasing development of new culture in $100 \%$ leads for using management by wandering in $21 \%$. Thus, the significant estimator formulated $t$ value for the test which is 0.038 , that is $5 \%$ less as illustrated in Table 10.

The following table shows that the significant estimator has formulated a p-value for $\mathrm{f}$ test which is (0.038), it's 5\% less as illustrated in Table 11 . The following table approves that there is a meaningful relationship between the dimensions of cultural organization (staff development, constancy and courtesy, new culture) and the dimensions of management by wandering (effective communication, facilitating organizational tasks and good treatment) as illustrated in Table 12. Where the sign $(*)$ refer to the significance of the correlation coefficient 0.05 and $* *$ the significance of correlation coefficient 0.01 . The highest correlation factor is between good treatment and staff development which is 0.509 , the p-value is 0.01 while the highest correlation factor was between facilitating organizational tasks and effective communication which is 0.503. Generally, all correlations were significantly high.

\section{CONCLUSION}

The significant role of management by wandering in the company, study sample and its active role in achieving tasks. Researchers and writers believe that cultural organization is the key to management by wandering and cultural organization, in turn is the key for competitive advantages. The agreement of research samples was very good, this indicates that management is aware of the variable importance according to the following: firstly, the agreement of cultural organization variables was excellent, this indicates the effective role of management by wandering around on achieving cultural organization. secondly, the variable of management by wandering around has achieved a high average. Thus, the cultural organization is crucial for achieving high average in different stages. Thirdly, there is a strong and meaningful relationship between management by wandering around and cultural organization. fourthly, $t$ value test shows the impact of staff on activating management by wandering around as the significance level is 0.012 , its $5 \%$ less. 


\section{RECOMMENDATIONS}

The study recommended the following: the necessity to educate the senior management officers of the environmental analysis and observe the variables in the external and internal environment. Paying further attention to the training courses and increase them in the fields that work on developing and improving the performance. Adopt test results to recognize the major concepts, strategies and means of influencing employees. Value employees as they are one of the important resources for the company. In addition, employees should take their manager as a role model. Mangers should be knowledgeable of management by wandering around (good treatment, facilitating organizational tasks and effective communication) and cultural organization (staff development, constancy and courtesy and a new culture). Hold training courses for managers to familiarize them with management by wandering around advantages. Create an ethical environment among managers and employees. Moreover, accept and encourage suggestions from employees. And this is the main concept of management by wandering around.

\section{REFERENCES}

Al-Ma’ani, W., E.F. Solomayer and M. Hammadeh, 2014. Expectant versus surgical management of firsttrimester miscarriage: A randomised controlled study. Arch. Gynecology Obstetrics, 289: 1011-1015.

Be'eri-Shlevin, Y., M. Eyal, Y. Eyal, M.J. Whitehouse and B. Litvinovsky, 2012. The Sa'al volcanosedimentary complex (Sinai, Egypt): A latest Mesoproterozoic volcanic arc in the Northern Arabian Nubian Shield. Geology, 40: 403-406.

Beil-Hildebrand, M., 2006. The implications of management by walking about: A case study of a German hospital. Leadership Health Serv., 19: 1-15.

Benabderrahmane, M.W., L.N. Pouchet, A. Cohen and C. Bastoul, 2010. The polyhedral model is more widely applicable than you think. Proceedings of the International Conference on Compiler Construction (CC’10), March 20-28, 2010, Springer, Berlin, Germany, pp: 283-303.

Bhagwat, A.A., 2015. Free speech without democracy. UCDL. Rev., Vol: 49,

Connolly, S.J., C.R. Kerr, M. Gent, R.S. Roberts and S. Yusuf et al., 2000. Effects of physiologic pacing versus ventricular pacing on the risk of stroke and death due to cardiovascular causes. N. Engl. J. Med., 342: 1385-1391.

Dirat, B., L. Bochet, M. Dabek, D. Daviaud and S. Dauvillier et al., 2011. Cancer-associated adipocytes exhibit an activated phenotype and contribute to breast cancer invasion. Cancer Res., 71: 2455-2465.
Gilbert, J.S., A.L. Lang, A.R. Grant and M.J. Nijland, 2005. Maternal nutrient restriction in sheep: Hypertension and decreased nephron number in offspring at 9 months of age. J. Physiol., 565: 137-147.

Gonnella, J., 2011. Columns and Hieroglyphs: Magic Spolia in Medieval Islamic Architecture of Northern Syria. In: Muqarnas, Necipo?lu, G. and K. Leal (Eds.). Brill Publishers, Leiden, Netherlands, ISBN: 978900419110527, pp: 103-120.

Hammid, A.T. and M.H. Sulaiman, 2017. Optimal long-term hydro generation scheduling of Small Hydropower Plant (SHP) using metaheuristic algorithm in Himreen lake dam. Proceedings of the MATEC Web Conference on UTP-UMP Symposium on Energy Systems (SES’17) Vol. 131, October 25, 2017, EDP Sciences, Les Ulis, France, pp: 04017-04021.

Hammid, A.T. and M.H.B. Sulaiman, 2018. Series division method based on PSO and FA to optimize long-term hydro generation scheduling. Sustainable Energy Technol. Assess., 29: 106-118.

Hammid, A.T., 2013. Applications of tuning control actions for the efficient load/frequency control in steam turbine. Intl. J. Curr. Eng. Technol., 3: $1895-1898$.

Hammid, A.T., 2016. Direct on line starter motor and reverse system in Allen-Bradley PLC. Diyala J. Pure Sci., 12: 132-148.

Hammid, A.T., A.K. Bhardwaj and S. Prakash, 2013. Design remote power control I/O data acquisition system and control on home automation. Intl. J. Electron. Commun. Comput. Eng., 4: 528-535.

Hammid, A.T., M. Hojabri, M.H. Sulaiman, A.N. Abdalla and A.A. Kadhim, 2016. Load frequency control for hydropower plants using PID controller. J. Telecommun. Electron. Comput. Eng., 8: 47-51.

Hammid, A.T., M.B.H. Kadhim, A.A. Sulaiman, A.N. Kareem and K.J. Jadaa, 2017a. Priority of Kaplan turbine and small hydropower plants over other resources: An overview. J. Eng. Applied Sci., 12: 8695-8705.

Hammid, A.T., M.H. Sulaiman and A.A. Jasim, 2018d. Modeling of hydropower plant production using artificial neural network. J. Adv. Res. Dyn. Control Syst., 10: 1526-1539.

Hammid, A.T., M.H. Sulaiman and H.J. Kareem, 2018b. Control on hydropower plant using fuzzy neural network based on right-angle triangle membership. J. Adv. Res. Dyn. Control Syst., 10: 1239-1250.

Hammid, A.T., M.H. Sulaiman and Y.K. Hameed, 2018c. Control on hydropower plant modeling using fuzzy neural network based on normalized firefly algorithm. J. Adv. Res. Dyn. Control Syst., 10: 1379-1392. 
Hammid, A.T., M.H.B. Sulaiman and A.A. Kadhim, 2017a. Optimum power production of Small Hydropower Plant (SHP) using Firefly Algorithm (FA) in Himreen Lake Dam (HLD), Eastern Iraq. Res. J. Appl. Sci., 12: 455-466.

Hammid, A.T., M.H.B. Sulaiman and A.N. Abdalla, 2018. Prediction of small hydropower plant power production in Himreen Lake dam (HLD) using artificial neural network. Alexandria Eng. J., 57: 211-221.

Hammid, A.T., M.H.B. Sulaiman and O.I. Awad, 2018. A robust firefly algorithm with backpropagation neural networks for solving hydrogeneration prediction. Electr. Eng., 100: 2617-2633.

Hammid, A.T., O.A. Imran and Y.K. Hameed, 2019. Executing work principle star/delta starter in motor systems using Allen-Bradley PLC. J. Eng. Applied Sci., 14: 1805-1812.

Hu, L.T. and P.M. Bentler, 1999. Cutoff criteria for fit indexes in covariance structure analysis: Conventional criteria versus new alternatives. Struct. Equat. Modell., 6: 1-55.

Jaradat, M.R., J.A. Feurtado, D. Huang, Y. Lu and A.J. Cutler, 2013. Multiple roles of the transcription factor AtMYBR1/AtMYB44 in ABA signaling, stress responses and leaf senescence. BMC. Plant Biol., Vol. 13, 10.1186/1471-2229-13-192
Mirtaheri, S.A., 2016. Transnational capitalism and the Middle East: Understanding the transnational Elites of the Gulf Cooperation Council. Ph.D. Thesis, Florida International University, Miami, Florida.

Ripke, S., C. O'Dushlaine, K. Chambert, J.L. Moran and A.K. Kahler et al., 2013. Genome-wide association analysis identifies 13 new risk loci for schizophrenia. Nat. Genet., 45: 1150-1159.

Sakarneh, A. and K.A.H. Ibrahim, 2011. A study on the internet financial reporting disclosure: A case of companies at Amman Stock Exchange, Jordan. Master's Thesis, Universiti Utara Malaysia, Changlun, Malaysia.

Thomas, J.R. and K.E. French, 1985. Gender differences across age in motor performance: A meta-analysis. Psychol. Bull., 98: 260-282.

Toth, J.D.M., Z.A. Karcioglu, A.A. Moshfeghi, T.M. Issa, J.R. Al-Ma'ani and K.V. Patel, 2000. The relationship between human papillomavirus and p53 gene in conjunctival squamous cell carcinoma. Cornea, 19: 159-162.

Venters, W. and E.A. Whitley, 2012. A critical review of cloud computing: Researching desires and realities. J. Inf. Technol., 27: 179-197. 